\title{
The main geo-environment problems and countermeasure research of the coastal zone of Pearl River Estuary
}

\author{
Zeng $\min ^{1}$,Liu Feng-mei ${ }^{1}$ \\ ${ }^{1}$ Wuhan Center,China Geological Survey,Wuhan,Hubei,China
}

\begin{abstract}
Keywords:COASTAL ZONE, PEARL RIVER ESTUARY, GEO-ENVIRONMENTAL PROBLEMS, COUNTERMEASURE RESEARCH
\end{abstract}

Abstract. The pearl river delta is not only located at the north of the south China sea, but also at the forefront of reform and opening up and economic development, while it is the most intense interaction in the land-sea relationship and outstanding contradiction in the human-earth relationship. On the basis of interaction of natural process and man-made reconstruction, it brings a series of geoenvironmental problems, which are as follows: large scale of land reclamation, widely developed mucky soft soils, land subsidence and saltwater intrusion caused by groundwater overdraft, aggravation of coastal erosion and estuary sedimentation, waste pollution, destruction of landscape ecological resources, geological disaster of coastal slope and underwater landslides caused by sand mining, and so on. This problems show the characteristics of long-term and continuously, abrupt change and gradual change. According to present state of geo-environmental problems, it can get the internal, external, motivation of problems by summarized the main types and the basic characteristics, which are sea level rise, human activities, and sudden climate and geological disasters. Based on the analysis above, it proposes countermeasures and suggestions as a basis for the prevention and control of geological environment problems.

\section{Introduction}

Coastal zone is the integration of land-sea, where is the interaction zone of the earth's surface, is not only natural environment system, but also social economic regional concept ${ }^{[1]}$. It have been destroyed the original natural environment seriously by the development of economy, global environmental change have affected the coastal zone environment ${ }^{[2]}$. Based on complex conditions of natural environment and geological in coastal zone, there are more and more geological disasters while geological environment have been suffered severe damage with the large-scale economic development since the reform and opening up. Especially, due to the sea level rise caused by greenhouse effect in recent years, it would lead to more complicated geological environment in the coastal zone. It will have serious impact to the evolution of the coastal environment in the future and the development of social economy. It is a global problem that deserves attention ${ }^{[3]}$.

The coastal zone of Pearl River Estuary belongs to the ecological ecotone between sea and land, which is a sensitive and fragile area of geological environment.

\section{Main geo-environmental problems}

The coastal zone of Pearl River Estuary is a typical interaction zone of sea, land, river. The coastal zone is influenced by many kinds of comprehensive factors which are regional geology structure, provenance characteristics, neotectonics, sea level fluctuation, geographic and geomorphic conditions, climatic factor, ocean hydrological dynamics characteristics, and so on. The formation of the coastal zone is composed of two factors which are regional geology structure as internal factor and geographic and geomorphic conditions, climatic factor, ocean hydrological dynamics characteristics as external factors. Besides, human activity have become an important part of geologic environmental impact factors increasingly drived by high-speed economic growth. It destroyed the geological 
environment and lead to a series of geo-environmental problems which consist of land reclamation, Excavation of sea sand, groundwater overdraft, waste pollution, and so on.

Large scale of land reclamation Land reclamation is an important project of coastal zone development activities, and an important method of expand living space and production space by human. The Pearl River Delta is growing by about 100 million tons of sediment every year. According to calculation, it stretched to the sea average about $27 \mathrm{~m}$ every year. There are somewhere spread faster to reach $63 \mathrm{~m}$ a year, such as Wanqingsha. The sediment also formed wide tidal flats in the delta front. land reclamation changed the Marine hydrodynamic conditions and reduce the tidal volume in harbour, weaken water self-purification ability, lead to seawater quality decline and sediment accumulation eventually.

Mucky soft soils widely developed The distribution area of mucky soft soils is about $8000 \mathrm{~km} 2$ in Pearl River Delta. The uneven sedimentation can be seen everywhere, both sides of reclamation and tidal flats of delta as a typical. The total sedimentation volume of residence and factory building is $0.3 \sim 1.5 \mathrm{~m}$ general. There are ground subsidence and skew cracking of low-rise building built on soft soil crust directly, and floor fall and dangling outseam of the high-level architecture built on bedrock. Soft ground deformation is a serious influence factors of Construction engineering, hydraulic engineering, underground water supply networks, and so on. It can cause enormous economic loss easily.

Land subsidence and saltwater intrusion caused by groundwater overdraft There is ground subsidence of parts of the Pearl River Delta because of groundwater overdraft. It makes the relative sea level rise rate is more than the rising rate of global change. Sea level rise can flood coastal lowlands, aggravate the loss of seawater intrusion and storm; while ground subsidence can damage the ground buildings and underground facilities, also can cause problems of sea water encroachment, coastal swamping, water quality deterioration, and so on. For example, the more than 40 years data of 33 measuring station show sea level rise have aggravated flood damage because of the highest flood level rises year by year reach to $14 \mathrm{~mm} / \mathrm{a}$.

Aggravation of Coastal erosion and estuary sedimentation The Pearl River Estuary is alluvial coast zone which its silting rate can reach to $40 \sim 160 \mathrm{~m} / \mathrm{a}$. So, the river estuary advance to the sea constantly because of the growing estuarine shoal and The acceleration of land reclamation. Tacking Shenzhen City as an example, the coast sedimentation phenomenon mainly distributed in the west coast. Since 1962, the coastline advance to sea from hundreds of meters to more than $1000 \mathrm{~m}$ generally, which at an speed of $17 \sim 55 \mathrm{~m} / \mathrm{a}$. The phenomena of siltation is very serious, so the bay coastline of shekou, chiwan, and mawan between Shenzhen bay and qianhai bay may become straight which can clag the development of port and wharf.

Waste pollution "Three wastes" pollution is everywhere because of dense population and welldeveloped industries in the pearl river delta. It is not only affects human health, and rivers, lakes, sea and aquatic, but also undermines freshwater resources which are municipal and industrial waste water, life rubbish and industrial waste. Besides, increasing exhaust emission could affect human health, and exacerbate the climate significantly because of greenhouse-warming effect.

Destruction of landscape ecological resources Recent years, there is the destruction of the landscape resources and ecological environment because of relatively extensive mode of development. 
Such as: serious damage of mangroves and coral reefs, degradation of coastal wetland, pelitization of sandbeach, deterioration of water quality, decrease of biodiversity, and so on. The Pearl River Estuary was spawning ground and fish breeding field of more than 200 kinds fish. So far, there is the sharp decline in fish population of just more than 50 kinds fish. As a result, there is decline of fish catch from the 1990s of 20 million $\mathrm{Kg}$ to 2 million $\mathrm{Kg}$ in recent years ${ }^{[4]}$.

Geological disaster of Coastal slope and underwater landslides caused by Sand mining Coastal highway exists several potential geological hazards to threat traffic and pedestrians, such as slope landslide, because of complicated geologic conditions and extensive development. In addition, excavation phenomenon of sea and river sand is obvious that change the water current environment to cause flood because of sediment imbalance, and change the slope stability of underwater bank to cause underwater landslide.

\section{Characteristics analysis of geo-environment problems}

The characteristics of long-term and continuously Theoretically, the sea level rise rate in Pearl River Estuary is $1.8 \mathrm{~mm} / \mathrm{a}$. Huang-Zhenguo predicted that the relative sea level will increase $22 \sim 33 \mathrm{~cm}$ from 1990 to $2030^{[5]}$. National marine information center estimates that when sea level rise to $30 \mathrm{~cm}$, the consequences will be severe. It contains that about $1719 \mathrm{~km} 2$ in the Pearl River Delta can be submerged and the emergence of storm surge frequency can increase about 5 times. Under the effect of tide, it can causes the upstream of seawater to affect the supply of fresh water and the deposition of river sediment with sea level rise. It can causes a series of geo-environment problems, such as coastal erosion, estuary sedimentation, embankment instability, uneven sedimentation, pelitization of sandbeach, and so on.

The characteristics of abrupt change and gradual change The sudden climate changes, storm and regional drought, can expand the adverse impact of sea level rise and further enlarge geoenvironment problems. At the storm time, the waves of shallow water can be longer than even to erode the coastline and spoil the groundwater. At the time of drought, it causes rapid deposition of estuary and uneven sedimentation.

Sea level rise can increase the frequency and intensity of storm surge to form coastal erosion. The embankment can not withstand the 20-year frequency of the flood which designed to withstand the 100-year frequency. The sea level rise have aggravated storm surge disasters because of the highest tide level of 23 tide station is lower than the measured highest water level $0.4 \sim 1.3 \mathrm{~m}$, such as Guangdong daya bay nuclear power station, Huangpu port, Macao airport, etc ${ }^{[6]}$. According to statistics, in recent 10 years, the storm surge frequency of coastal zone of guangdong have increased 1.5 times than before. In September 2008, super typhoon "hagupit" triggered 100-year frequency storm surge because of the sea level more than $200 \mathrm{~mm}$ higher than all the year round. In September 2013, super typoon "usagi" triggered heavy rainfall of $250-300 \mathrm{~mm}$ in the coastal areas of east of Pearl River Estuary because of astronomical tide period of more than warning water level. In the 21 st century, the coastal area in china can be affected by typhoon and storm surge disasters than $20 \mathrm{st}$ century $^{[7]}$.

From the comprehensive analysis above, it can get the internal, external, motivation of problems, which are Sea level rise, human activities, and sudden climate and geological disasters. There are all kinds of geo-environment problems because of the influence of a series of factors. According to summarized the main types and the basic characteristics, we can get the following contents from the countermeasure research. 


\section{Countermeasures research}

Strengthen basic geology and problem mechanism research to further improve the understanding of geo-environmental problems It is necessary that Strengthen basic geology and problem mechanism research. First, It can find out present state, characteristics and process of problems by basic geological survey; second, it can improve the accuracy of the practical work largely by problem mechanism research.

The monitoring system, that the development trend of geologic environmental problems of real-time monitoring, should be constructed Geologic environment monitoring system is basic measure for process and change of geo-environment investigation. It Is also the basic platform of geologic environmental research. It can analyze the process, change and trend of geo-environment and impact of human activities by monitoring of sea level eustacy, uneven sedimentation, water flow and sediment transport, Coastal erosion and estuary sedimentation, Dynamic balance of fresh and salt water underground, and so on.

Scientific planning layout is to avoid geo-environmental problems strategically The river of Pearl River Delta should be managed and planned by "Dredge channel " principle. The land reclamation should consider the "unlock " principle to give enough width for estuary in order to drainage and sediment deposition. The Coastal project should be planned scientific to resist storm surge and avoid pollution and uneven sedimentation. Besides, construction of ecological wetland park can protect the ecological resources, such as wetland and mangrove.

Pay attention to management and legislation can ensure the full implementation of prevention and control of geo-environmental problems The prevention and control of geo-environmental problems is not only involves the technique, but also cause a series of related social and economic problems from control measures. It can achieve result of monitoring and control on the premise of law, policy and fund, under the strong support of the government.

\section{Summary}

The coastal zone, there are complicated geo-environment problems in the Pearl River Estuary, is a complex system. It can produce great difficulties to the prevention and control. It should be investigated and researched in many ways, such as regional investigation and research, Basic research, technology research, monitoring and evaluation, etc. The countermeasures and suggestions based on the geological environment investigation and research could provide reliable basis for integrated coastal zone management and region sustainable development.

\section{References}

[1]ZHANG Xun-hua, LU Jing, YIN Ping, LIU Jian, Challenges and missions of coastal geological investigation in China, Marine Geology Frontiers,2011,27(1):1-7,41.

[2]XIA Zhen, LIN Jin-qing, ZHENG Zhi-chang, Integrated investigation methods for the marine geo-environment in coastal zones. Geological Bulletin of China, 2005, 24(6):570-575. 
[3]CHEN Meng-xiong, The City Geo-Environmental characteristics on China coastal zone and the major Geo-Environment problems. Proceedings of Coastal Geo-environment and urban development, china land press, 2005-2008,8-14.

[4]HAN Yong-wei, GAO Ji-xi, LI Zheng-hai, LIU Yun-bo, The main ecological environmental problems and protection measures in pearl river delta coastal zone. Ocean Development and Management, 2005(3):84-87.

[5]HUANG Zhen-guo, ZHANG Wei-qiang, WU Hou-yong, FAN Jin-chun, JIANG Pei-lin, CHEN Te-gu, LI Zi-hao, HUANG Ben-sheng, The sea level rise forecast and defense strategy in 2030 in the pearl river delta. Science in China(Series D), 2000,30(2):202-208.

[6]JIN Qing-huan. The environmental protection and Marine economy sustainable development of Guangdong coastal zone, hydrogeology and engineering geology, 2004(4):31-32.

[7]WEN Dong-guang, WU Deng-ding, ZHANG Er-yong, The main environmental geological problems of China coastal zone, Proceedings of Coastal Geo-environment and urban development, china land press, 2005-2008,29-35. 